Tahani A Al-Sandook BDS, PhD (Prof.)

Rayia J Al-Naimi BDS, MSc (Asst. Prof.)

Karam H Jazrawi BDS, MSc (Lec.)

\section{Trends of Oral Diseases and Treatment Needs in 13-15 Year Old Students in Mo- sul City Center}

\author{
Department of Dental Basic Sciences \\ College of Dentistry, University of Mosul
}

Dept of Pedod, orthod, and Prev Dentistry

College of Dentistry, University of Mosul

Dept of Pedod, orthod, and Prev Dentistry

College of Dentistry, University of Mosul

$$
\begin{aligned}
& \text { الخلاصة } \\
& \text { ألاهداف: لتحديد الاتحاهات في أمراض الفم (تسوس الأسنان وأمراض ما حول الأسنان) لدى بحموعة من طلبة المدارس المتوسطة (با -0 إسنة) } \\
& \text { واحتياجاهم العلاجية. المواد وطرائق العمل: تم فحص (7 الماهد) طالب وطالبة من طلاب المدارس المتوسطة وتقييم تسوس الأسنان والاحتياجات } \\
& \text { العلاجية لهم وفقا للمبادئ التوجيهية لمنظمة الصحة العالمية (9991 ). تم إجراء تقييم لصحة اللثة والاحتياجات العلاجية للطلاب باستخدام مؤشر } \\
& \text { (CPITN) }
\end{aligned}
$$

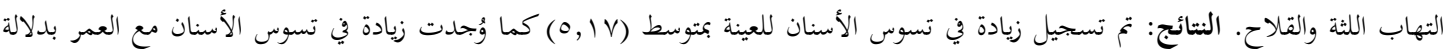

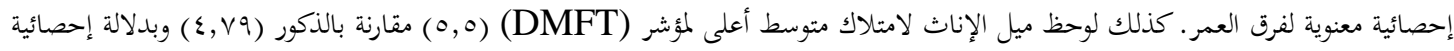

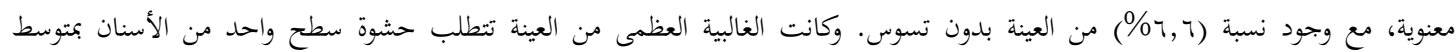

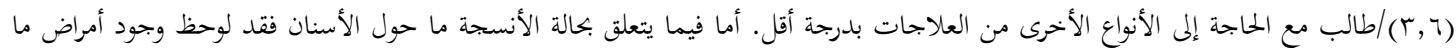

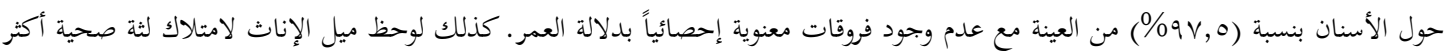

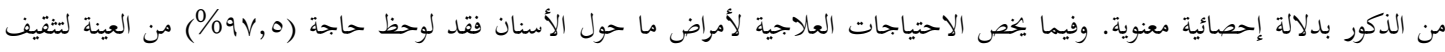

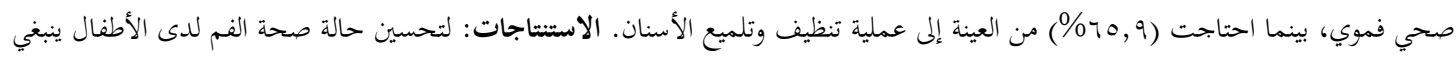

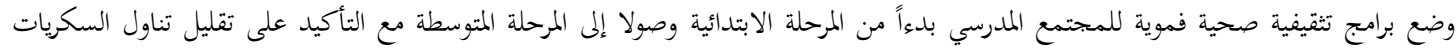

$$
\begin{aligned}
& \text { وإتباع التدابير الصحية الفموية، ويمكن استخدام الفلوريدات وسدادات شقوق الأسنان بصورة فعالة أيضاً. }
\end{aligned}
$$

\title{
ABSTRACT
}

Aims: To determine the trends of the two major dental diseases (dental caries and periodontal disease) in a group of 13-15 year old intermediate school and their treatment needs. Materials and Methods: A total of 516 intermediate school students were examined. Dental caries and treatment needs were assessed according to the WHO 1997 guidelines. The assessment of the gingival health and treatment needs of the students was performed using the CPITN index as recommended by the WHO 1987. Six index teeth were examined and the presence of gingival bleeding and calculus was recorded. Results: Dental caries in the sample has increased with a mean of 5.17. Dental caries increased with age with a statistically significant age difference. Females tended to have a higher DMFT of 5.5 compared to males 4.79 with significant difference, only $6.6 \%$ of the sample was caries free. The majority of the samples needed one surface fillings with a mean of 3.6/child. Other dental treatments were needed to a lesser extent. Regarding the periodontal status, the disease was present in $97.5 \%$ of the sample, there was no significant age difference regarding periodontal health. Females tended to have a healthier gingiva compared to males with significant difference. Regarding periodontal treatment needs, $97.5 \%$ of the sample required dental health education, while $65.9 \%$ required professional scaling and polishing. Conclusions: To improve children's oral health, community school-based oral health educational programs should be established starting from primary and extending to intermediate schools, stressing on sugar restriction and oral hygiene measures, fluorides and fissure sealants can effectively be used too. Key words: Dental caries, sugar, periodontal disease, gingival bleeding, calculus.

Al-Sandook TA, Al-Naimi RJ, Jazrawi KH. Trends of Oral Diseases and Treatment Needs in 13-15 Year Old Students in Mosul City Center . Al-Rafidain Dent J. 2013; 13(2): 241-250.

Received: 3/1/2012 Sent to Referees: $5 / 1 / 2012$ Accepted for Publication: 27/2/2012 


\section{INTRODUCTION}

Oral health remains a global problem and therefore requires global concern (1) $^{(1)}$ Despite a great improvement in the oral health, problems still persist, particularly among underprivileged groups both in developed, and developing countries. ${ }^{(2)}$ Oral diseases are highly prevalent, and their impact on both society and the individual are significant: pain, disability, and handicap. ${ }^{(3)}$ The experience of pain, problems with eating, chewing, smiling, and communication due to missing, discolored or damaged teeth have a major impact on people's daily lives, and well-being. Furthermore, oral diseases can restrict people's activities at school, at work, and at home, causing millions of lost school and work hours each year throughout the world. ${ }^{(4)}$

Dental caries is the result of mineral loss of dental hard tissues attributable to the activity of biofilm on the tooth surface. As a multi-factor disease, the extent and rate of dental caries depend on physical and biological risk factors, including inadequate salivary flow and composition, high numbers of cariogenic bacteria, insufficient fluoride exposure, and genetic factors. ${ }^{(5)}$ Dental caries is, moreover, related to one's behaviour and lifestyle. These behavioural factors include poor oral hygiene and frequent consumption of refined carbohydrates. $^{(6)}$

Periodontal diseases, on the other hand, are highly prevalent and can affect $90 \%$ of the worldwide population. ${ }^{(7)}$ The mildest form of periodontal disease is gingivitis which result from accumulation of dental plaque on the tooth adjacent to the gingiva. ${ }^{(8)}$ The signs of gingivitis are distinguishable among most children and adolescents worldwide. ${ }^{(9)}$ Gingivitis can be well seen as a behavioural disease; it is reversible by simple and effective oral hygiene. ${ }^{(7)}$ The effective removal of dental plaque is essential to dental and periodontal health throughout life. ${ }^{(10)}$

The aim of this study is to determine the trends of the two major dental diseases (dental caries and periodontal disease) in a group of 13-15 year old intermediate school students as a previous survey had been conducted 13 years prior to this one and to determine the treatment needs for this age group.

\section{MATERIALS AND METHODS}

A legal permit and written statement were obtained from the Directorate of Education to conduct clinical oral examinations during school hours, and 6 randomly selected intermediate schools were chosen ( 3 for boys and 3 for girls from the city center representing different socioeconomic status).Students chosen randomly from the list were examined in a suitable room, the assessment of the oral health status and treatment needs was registered in a special form .Information regarding name, age and gender of the students was registered prior to the dental examination.

Oral Examination

Dental examinations were performed by only one calibrated examiner under natural daylight using dental mirrors and sickle shaped dental caries explorers. All examination instruments were sterilized in dry heat. Examination was performed using the WHO standard criteria and procedures. ${ }^{(11)}$ A systematic approach was used for the assessment of the dentition status and treatment needs, starting from the upper right second molar proceeding in an orderly manner. Dental caries was measured in DMFT values. ${ }^{(12)}$ Immediately after the status of a tooth was recorded and before proceeding to the next tooth or tooth space, the type of dental treatment need required, if any, was recorded depending upon the examiner's own clinical judgment. Dental treatments included one surface fillings, two or more surfaced fillings, veneer or laminate, pulp care, extractions and space maintaining appliances. ${ }^{(11)}$

The assessment of the gingival health and treatment needs of the students was performed using the CPITN as recommended by the WHO $1987^{(13)}$, with use of a special designed light weighted periodontal probe (WHO probe), the probe had a ball tip of $0.5 \mathrm{~mm}$ and a black band situated at a distance between 3.5 and $5.5 \mathrm{~mm}$ from the ball tip. The ball end allows for the detection of the supra and sub gingival calculus.

The mouth is divided in to six sextants defined by the teeth numbers; 17-14, 13$23,24-27,37-34,33-43$ and $44-47$ for the permanent dentition, each sextant was 
considered as a basic unit of examination and treatment need. According to WHO guidelines, ${ }^{(13)}$ the index teeth that should be examined for individuals aged 20 years and over are; 17, 16, 11, 26, 27 , 37, 36, 31, 46, 47.

The modification of examining 6 index teeth instead of 10 in young people up to the age of 19 years was made in order to avoid classifying crevices associated with the eruption of the second molars as periodontal pockets ${ }^{(14)}$ so index teeth examined were: 16, 11, 26, 36, 31, 46.

If index tooth was not present, all remaining teeth in that sextant were examined and the worst score was recorded for that sextant. ${ }^{(13)}$ The coding for the CPITN in an ascending order of severity is:

Code $4=$ Pathological pocket $6 \mathrm{~mm}$ or deeper.

Code 3 = Pathological pocket $4-5 \mathrm{~mm}$ deep.

Code $2=$ Supra or sub gingival calculus.

Code $1=$ Gingival bleeding after gentle probing

Code $0=$ No signs of the disease.

For children under 15 years of age, only presence or absence of gingival bleed- ing and calculus should be recorded due to the presence of false pockets associated with the eruption of permanent teeth which will give misleading results. The code numbers recorded indicated the following type of periodontal treatment: ${ }^{(11,13)}$ $0=$ No need for periodontal treatment $1=$ Oral hygiene education

$2=$ Scaling + Oral hygiene education

$3=$ Scaling + Oral hygiene education 4 = Complex treatment + Scaling + Oral hygiene education

As periodontal pocket was not measured, the periodontal treatment codes 3 and 4 were not used.

The data were recorded and analyzed using the Statistical Package for the Social Sciences version 11.0, descriptive analysis including mean, standard deviation, frequency and percentages, Student's t test, Duncan's Multiple Range test and Chi square test were performed when indicated, results were significant when $\mathrm{p} \leq 0.05$.

\section{RESULTS}

Distribution of the sample by age and gender is shown in Table (1)

Table (1): Distribution of the sample by age and gender

\begin{tabular}{|c|c|c|c|}
\hline Age (Years) & Sex & No. & $\%$ \\
\hline \multirow{3}{*}{$8-(12.0)$} & Males & 79 & 15.3 \\
\hline & Females & 76 & 14.7 \\
\hline & Total & 155 & 30 \\
\hline \multirow{3}{*}{14} & Males & 81 & 15.7 \\
\hline & Females & 95 & 18.4 \\
\hline & Total & 176 & 34.1 \\
\hline \multirow{3}{*}{15} & Males & 80 & 15.5 \\
\hline & Females & 105 & 20.3 \\
\hline & Total & 185 & 35.9 \\
\hline \multicolumn{2}{|c|}{ Total Males } & 240 & $46.5 \%$ \\
\hline \multicolumn{2}{|c|}{ Total Females } & 276 & $53.5 \%$ \\
\hline \multicolumn{2}{|c|}{ Total Sample } & 516 & $100 \%$ \\
\hline
\end{tabular}

The sample composed of 516 students distributed among 3 age groups 13,14 and 15 year olds representing first, second and third year of intermediate schooling (240 male $46.5 \%$ and 276 females $53.5 \%$ ).

Table (2) displays mean DMFT values and components in the 3 age groups and total sample. Dental caries was increasing with increasing age with a statistically significant age difference as it was 3.93 for 13 year olds, increasing to 5.3 for 14 year old and became 6.08 in 15 year olds.

Females tended to have a higher DMFT value 5.50 compared to males 4.79 with a statistically significant gender difference. For the components of the DMFT, the decayed portion (DT) contributed most of the DMFT index in both males and females, with significant differences in females compared to males, yet no differences where observed in the missing (MT) and filled component (FT) between them. 
Table (2): Mean DMFT and Its Components by Age and Gender

\begin{tabular}{|c|c|c|c|c|c|c|c|c|c|c|}
\hline \multirow{2}{*}{$\begin{array}{c}\text { Age } \\
\text { (Years) }\end{array}$} & \multirow{2}{*}{ Gender } & \multirow{2}{*}{ No. } & \multicolumn{2}{|c|}{ DMFT } & \multicolumn{2}{|c|}{ DT } & \multicolumn{2}{|c|}{ MT } & \multicolumn{2}{|c|}{ FT } \\
\hline & & & Mean & \pm SD & Mean & $\pm \mathrm{SD}$ & Mean & $\pm \mathrm{SD}$ & Mean & \pm SD \\
\hline \multirow[b]{2}{*}{13} & Males & 79 & 3.32 & 2.23 & 2.77 & 1.92 & 0.09 & 0.33 & 0.46 & 0.83 \\
\hline & $\begin{array}{c}\text { Females } \\
\text { Total }\end{array}$ & $\begin{array}{c}76 \\
155\end{array}$ & $\begin{array}{c}4.59 \\
3.93^{(\mathrm{A})}\end{array}$ & $\begin{array}{l}2.53 \\
2.46\end{array}$ & $\begin{array}{c}3.66 \\
3.21^{(\mathrm{A})}\end{array}$ & $\begin{array}{l}2.26 \\
2.13\end{array}$ & $\begin{array}{c}0.14 \\
0.12^{(\mathrm{A})}\end{array}$ & $\begin{array}{l}0.45 \\
0.39\end{array}$ & $\begin{array}{c}0.79 \\
0.62^{(\mathrm{A})}\end{array}$ & $\begin{array}{l}1.58 \\
1.26\end{array}$ \\
\hline \multirow[b]{2}{*}{14} & Males & 81 & 5.37 & 2.57 & 4.44 & 2.36 & 0.15 & 0.45 & 0.78 & 1.51 \\
\hline & $\begin{array}{c}\text { Females } \\
\text { Total }\end{array}$ & $\begin{array}{c}95 \\
176\end{array}$ & $\begin{array}{c}5.23 \\
5.30^{(\mathrm{B})}\end{array}$ & $\begin{array}{l}2.27 \\
2.41\end{array}$ & $\begin{array}{c}4.63 \\
4.55^{(\mathrm{B})}\end{array}$ & $\begin{array}{l}2.03 \\
2.18\end{array}$ & $\begin{array}{c}0.13 \\
0.14^{(\mathrm{A})}\end{array}$ & $\begin{array}{l}0.39 \\
0.42\end{array}$ & $\begin{array}{c}0.47 \\
0.61^{(\mathrm{A})}\end{array}$ & $\begin{array}{l}1.05 \\
1.29\end{array}$ \\
\hline \multirow[b]{2}{*}{15} & Males & 80 & 5.65 & 2.68 & 5.30 & 2.53 & 0.09 & 0.48 & 0.26 & 0.65 \\
\hline & $\begin{array}{c}\text { Females } \\
\text { Total }\end{array}$ & $\begin{array}{l}105 \\
185\end{array}$ & $\begin{array}{c}6.40 \\
6.08^{(\mathrm{C})}\end{array}$ & $\begin{array}{l}2.41 \\
2.55\end{array}$ & $\begin{array}{c}5.39 \\
5.35^{(\mathrm{C})}\end{array}$ & $\begin{array}{l}2.31 \\
2.40\end{array}$ & $\begin{array}{c}0.18 \\
0.14^{\text {(A) }}\end{array}$ & $\begin{array}{l}0.48 \\
0.48\end{array}$ & $\begin{array}{c}0.83 \\
0.58^{(\mathrm{A})}\end{array}$ & $\begin{array}{l}1.26 \\
1.08\end{array}$ \\
\hline \multicolumn{2}{|c|}{ Total Males } & 240 & 4.79 & 2.70 & 4.18 & 2.50 & 0.11 & 0.43 & 0.50 & 0.43 \\
\hline \multicolumn{2}{|c|}{ Total Females } & 276 & 5.50 & 2.50 & 4.65 & 2.30 & 0.15 & 0.44 & 0.70 & 1.30 \\
\hline \multicolumn{2}{|c|}{ Total Sample } & 516 & 5.17 & 2.62 & 4.43 & 2.41 & 0.13 & 0.43 & 0.60 & 1.21 \\
\hline
\end{tabular}

Student's t-test between males and females, DMFT: Value $=-3.112 ; \mathrm{df}=514 ; p$-value $=0.002(\mathrm{~S}), \mathrm{DT}$ : Value $=-2.236 ; \mathrm{df}=514 ; p-$ value $=0.026(\mathrm{~S}), \mathrm{MT}:$ Value $=-1.145 ; \mathrm{df}=514 ; p-$ value $=0.253(\mathrm{NS}) ; \mathrm{FT}$ : Value $=-1.844 ; \mathrm{df}=514 ; p-$ value $=0.066(\mathrm{NS})$

Figure (1) displays the percentage of the caries free students, only $6.6 \%$ of the total sample was caries free, with males showing a higher percentage of caries free $8.8 \%$ compared to females $4.7 \%$.

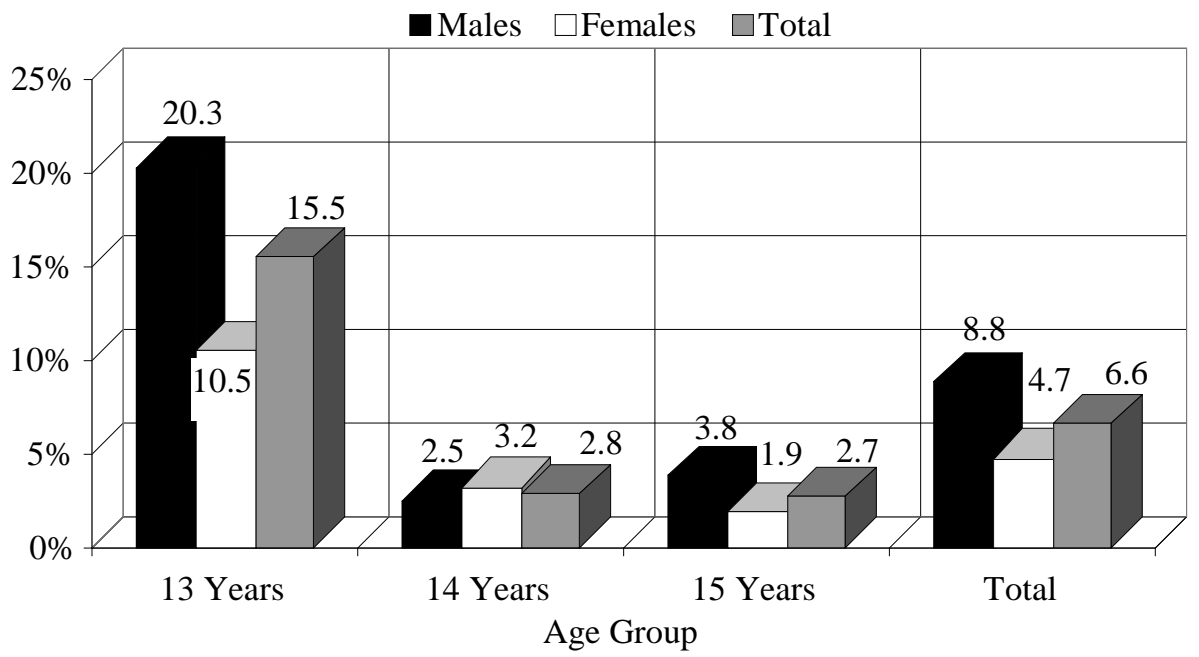

Figure (1): Caries Free Students by Age and Gender

Table (3) demonstrates the dental treatment needs of the students, majority of the students dental treatment needs included 1858 one surface fillings with a mean of 3.6 per child, followed by 306 two or more surface fillings with a mean of 0.59 , extractions indicated in 63 teeth, space maintainers, pulp care and finally veneers or laminates were indicated according to their prevalence. 
Table (3): Dental Treatment Need

\begin{tabular}{ccc}
\hline Type of Dental Treatment & $\begin{array}{c}\text { Number of Teeth } \\
\text { /frequency }\end{array}$ & $\begin{array}{c}\text { Treatment Need Per } \\
\text { Child }\end{array}$ \\
\hline One Surface Filling & 1858 & 3.60 \\
Two or More Surface Filling & 306 & 0.59 \\
Veneer or Laminate & 19 & 0.04 \\
Pulp Care & 35 & 0.07 \\
Extraction & 63 & 0.12 \\
Space Maintainer & 44 & 0.09 \\
\hline
\end{tabular}

Table (4) shows the number and percentage of students distributed according to the highest CPITN code by age and gender, only $2.5 \%$ of the sample had healthy gingiva, with females showing a higher percentage of healthy gingiva 3.6\% compared to males $1.2 \%$ with a statistically significant gender difference .Calculus was prevalent in $75 \%$ of males compared to $58 \%$ in females, with females tending to show a higher percentage of bleeding gingival $38.4 \%$ compared to males $23.8 \%$.

No significant age difference in periodontal health was seen in the three age groups. Healthy gingiva was found $2.6 \%$, $2.3 \%$ and $2.7 \%$ in 13,14 and 15 year olds respectively. The same picture is seen in case of bleeding and calculus with in the three age groups.

Table (4): Number and Percentage of Students Distributed According to the Highest CPITN Code by Age and Gender

\begin{tabular}{|c|c|c|c|c|c|c|c|c|}
\hline \multirow[t]{2}{*}{ Age (Years) } & \multirow[t]{2}{*}{ Sex } & \multirow[t]{2}{*}{ No. } & \multicolumn{4}{|c|}{$\begin{array}{l}\text { CPITN Code } \\
\text { Bleeding Code } \\
\text { (1) }\end{array}$} & \multicolumn{2}{|c|}{$\begin{array}{c}\text { Calculus Code } \\
\text { (2) }\end{array}$} \\
\hline & & & No. & $\%$ & No. & $\%$ & No. & $\%$ \\
\hline \multirow{4}{*}{13} & Males & 79 & 2 & 2.5 & 27 & 34.2 & 50 & 63.3 \\
\hline & Females & 76 & 2 & 2.6 & 35 & 46.1 & 39 & 51.3 \\
\hline & Total & 155 & 4 & 2.6 & 62 & 40.0 & 89 & 57.4 \\
\hline & Males & 81 & 0 & 0.0 & 14 & 17.3 & 67 & 82.7 \\
\hline \multirow[t]{3}{*}{14} & Females & 95 & 4 & 4.2 & 36 & 37.9 & 55 & 57.9 \\
\hline & Total & 176 & 4 & 2.3 & 50 & 28.4 & 122 & 69.3 \\
\hline & Males & 80 & 1 & 1.2 & 16 & 20.0 & 63 & 78.8 \\
\hline \multirow[t]{2}{*}{15} & Females & 105 & 4 & 3.8 & 35 & 33.3 & 66 & 62.9 \\
\hline & Total & 185 & 5 & 2.7 & 51 & 27.6 & 129 & 69.7 \\
\hline \multicolumn{2}{|c|}{ Total Males } & 240 & 3 & 1.2 & 57 & 23.8 & 180 & 75.0 \\
\hline \multicolumn{2}{|c|}{ Total Females } & 276 & 10 & 3.6 & 106 & 38.4 & 160 & 58.0 \\
\hline \multicolumn{2}{|c|}{ Total Sample } & 516 & 13 & 2.5 & 163 & 31.6 & 340 & 65.9 \\
\hline
\end{tabular}

Sex Difference: $\chi^{2}=17.248 ; \mathrm{df}=2 ; p-$ value $=0.000(\mathrm{~S})$, Age Difference $\chi^{2}=7.467 ; \mathrm{df}=4 ; p-$ value $=$ 0.113 (NS)

It can be depicted in Table (5) the mean number of healthy sextants for the total sample was 1.67 , with females showing a higher mean healthy sextant 2.04 compared to males 1.23 , also males tended to show higher means of periodontal disease related to gingival bleeding and presence of calculus with means of 2.9 and 1.87 respectively compared to females (2.67 and 1.28 , respectively). 
Table (5): Mean Number of Sextants Affected ( \pm Standard Deviation) per Student for Each Stage of the Disease by Age and Gender

\begin{tabular}{|c|c|c|c|c|c|c|c|c|}
\hline \multirow[t]{2}{*}{ Age (Years) } & \multirow[t]{2}{*}{ Sex } & \multirow[t]{2}{*}{ No. } & \multicolumn{4}{|c|}{$\begin{array}{l}\text { CPITN Code } \\
\text { Bleeding Code } \\
\text { (1) }\end{array}$} & \multicolumn{2}{|c|}{$\begin{array}{c}\text { Calculus Code } \\
\text { (2) }\end{array}$} \\
\hline & & & Mean & \pm SD & Mean & $\pm \mathrm{SD}$ & Mean & \pm SD \\
\hline \multirow{3}{*}{13} & Males & 79 & 1.23 & 1.38 & 3.16 & 1.30 & 1.61 & 1.66 \\
\hline & Females & 76 & 2.00 & 1.70 & 2.86 & 1.22 & 1.14 & 1.36 \\
\hline & Total & 155 & 1.61 & 1.59 & 3.01 & 1.26 & 1.38 & 1.53 \\
\hline & Males & 81 & 0.98 & 1.12 & 2.81 & 1.41 & 2.21 & 1.72 \\
\hline \multirow[t]{3}{*}{14} & Females & 95 & 2.21 & 1.92 & 2.41 & 1.23 & 1.38 & 1.52 \\
\hline & Total & 176 & 1.64 & 1.71 & 2.60 & 1.33 & 1.76 & 1.66 \\
\hline & Males & 80 & 1.50 & 1.36 & 2.71 & 1.14 & 1.79 & 1.49 \\
\hline \multirow[t]{2}{*}{15} & Females & 105 & 1.92 & 1.66 & 2.78 & 1.44 & 1.30 & 1.34 \\
\hline & Total & 185 & 1.74 & 1.55 & 2.75 & 1.32 & 1.51 & 1.42 \\
\hline \multicolumn{2}{|c|}{ Total Males } & 240 & 1.23 & 1.30 & 2.90 & 1.29 & 1.87 & 1.64 \\
\hline \multicolumn{2}{|c|}{ Total Females } & 276 & 2.04 & 1.76 & 2.67 & 1.32 & 1.28 & 1.41 \\
\hline \multicolumn{2}{|c|}{ Total Sample } & 516 & 1.67 & 1.62 & 2.78 & 1.31 & 1.56 & 1.55 \\
\hline
\end{tabular}

Table (6 ) displays the periodontal treatment needs of the students only $2.5 \%$ of the students required no treatment, while $97.5 \%$ of the sample required oral hygiene instructions and $65.9 \%$ of the sample needed scaling and polishing.

Table (6): Number and Percentage of Students Distributed According to the Treatment Need by Age and Sex

\begin{tabular}{|c|c|c|c|c|c|c|c|c|}
\hline \multirow[t]{2}{*}{ Age (Years) } & \multirow[t]{2}{*}{ Sex } & \multirow[t]{2}{*}{ No. } & \multicolumn{2}{|c|}{$\begin{array}{c}\text { No Need Code } \\
(\mathbf{0})\end{array}$} & \multicolumn{2}{|c|}{$\begin{array}{l}\text { Home Care } \\
\text { Instruction } \\
\text { (Codes 1\&2) }\end{array}$} & \multicolumn{2}{|c|}{$\begin{array}{c}\text { Scaling and } \\
\text { Polishing Code } \\
\text { (2) }\end{array}$} \\
\hline & & & No. & $\%$ & No. & $\%$ & No. & $\%$ \\
\hline \multirow{3}{*}{13} & Males & 79 & 2 & 2.5 & 77 & 97.5 & 50 & 63.3 \\
\hline & Females & 76 & 2 & 2.6 & 74 & 97.4 & 39 & 51.3 \\
\hline & Total & 155 & 4 & 2.6 & 151 & 97.4 & 89 & 57.4 \\
\hline \multirow{3}{*}{14} & Males & 81 & 0 & 0.0 & 81 & 100.0 & 67 & 82.7 \\
\hline & Females & 95 & 4 & 4.2 & 91 & 95.8 & 55 & 57.9 \\
\hline & Total & 176 & 4 & 2.3 & 172 & 97.7 & 122 & 69.3 \\
\hline \multirow{3}{*}{15} & Males & 80 & 1 & 1.2 & 79 & 98.8 & 63 & 78.8 \\
\hline & Females & 105 & 4 & 3.8 & 101 & 96.2 & 66 & 62.9 \\
\hline & Total & 185 & 5 & 2.7 & 180 & 97.3 & 129 & 69.7 \\
\hline \multicolumn{2}{|c|}{ Total Males } & 240 & 3 & 1.2 & 237 & 98.8 & 180 & 75.0 \\
\hline \multicolumn{2}{|c|}{ Total Females } & 276 & 10 & 3.6 & 266 & 96.4 & 160 & 58.0 \\
\hline \multicolumn{2}{|c|}{ Total Sample } & 516 & 13 & 2.5 & 503 & 97.5 & 340 & 65.9 \\
\hline
\end{tabular}

\section{DISCUSSION}

Childhood oral diseases can lead to irreversible damage, pain, disfigurement, more serious general health problems, lost school time, low self-esteem, and poor quality of life ${ }^{(14,15)}$ Iraq has been through two wars over the last two decades and suffered from 13 years of economic sanctions. Nutrition, the health sys- tem and daily living conditions of the Iraqi population have been profoundly influenced by the wars causing political and economical instability. During the last two decades, little has been published about the oral health status and oral health related behaviors of Iraqi children.

Results of this study showed a marked increase in dental caries experience Table 
(2) with a mean DMFT value of 5.17 for the total sample compared to a previous survey with a mean of 3.43 for the 13-15 year olds, ${ }^{(16)}$ with a mean of 2.67 for 13 year olds and increased to 4.29 in 15 year olds, the previous survey was conducted while Iraqi populations where suffering from United Nations sanctions as sugar consumption dropped from $50 \mathrm{~kg} /$ person / year to $12 \mathrm{~kg}$ / person/year and similar trends of reduction of dental caries were observed. ${ }^{(17)}$ Previous reports on the sweet preferences and dental caries in Iraqi children demonstrated that the level of sugar intake was high and that sugar consumption was positively associated with DMFT scores. Urban individuals showed a much higher preference and consumption of sugar than their rural counterparts. ${ }^{(18)}$ After 2003, the pattern of sugar consumption increased and returned to the previous state due to the availability of sugar containing confections and availability of sugar containing drinks, ${ }^{(19)}$ so one would predict that dental caries experience would increase. The mean DMFT value for 15 year olds in this study (6.08) is higher than that reported by WHO in many regions ${ }^{(20)}$ which was the lowest in Africa and highest in the Eastern Mediterranean like Lebanon with a mean DMFT of 5.4.

The DT contributed most to the DMFT (4.43) scores with a higher decayed portion in females compared to males with significant difference, indicating that untreated caries is a problem for the children investigated, this is in agreement with previous studies. ${ }^{(16,19)}$

There was no significant difference in gender regarding the filled and missing components, which contradicts the study of Ahmed et al. ${ }^{(19)}$ that found that filled component scores were higher in females than in males while DT and MT scores showed minor variation according to gender.

The percentage of caries free students in this study was 6.6 (Figure), which is much less than that reported by AlNaimi, ${ }^{(16)}$ that reported 16.42 caries free. This is attributed to the increased consumption of refined carbohydrates and sugar containing confections and drinks during the last decade. ${ }^{(6,19)}$

The majority of the treatment needs for the teeth were one surface fillings (Table 3 ) with a mean of $3.6 /$ child. This figure is more than that reported, ${ }^{(16)}$ with an increase of nearly $1.5 /$ child. Occlusal tooth surfaces with pits and grooves are more susceptible to decay in children and adolescents. The students also needed two or more surface fillings, and to a lower extent extractions, space maintaining appliances, pulp care and veneers or laminates. Oral diseases are the world's fourth most expensive disease to treat. ${ }^{(14)}$ Dental expenditure poses a problem for many emerging economies; the expenditure of providing traditional operative dental care could exhaust the whole country's health budget, a budget that is already fully stretched or even does not exist. ${ }^{(21)}$ Meanwhile, treatment approaches alone will never eradicate oral diseases, ${ }^{(22)}$ and the oral health of a population can not be improved merely by applying the restorative approach. ${ }^{(23)}$ Social and educational costs are also significant. ${ }^{(24)}$

In many developed countries caries has been tackled by implementing dental health educational programmes at schools ${ }^{(24)}$ stressing on dietary restriction of sugars, use of fluorides ${ }^{(25)}$ and sealants. ${ }^{(26)}$

The WHO recommends the use of Community Periodontal Index (CPITN) as an epidemiologic tool to increase international uniformity of epidemiological studies on periodontology. ${ }^{(11)}$ Based on the recommendation by the $\mathrm{WHO},{ }^{(11)}$ the CPITN index can serve for evaluation of the periodontal status of individuals, because of its simplicity, speed, and international uniformity. According to CPI scores, calculus, and gingival bleeding are common findings among 15-year-olds in the six WHO regions (WHO member status are grouped into 6 geographical regions which are AFRO "Africa", AMRO "Americas", EMRO "Eastern Mediterranean", EURO "Europe", SEARO "South East Africa" and WPRO "Western Pacific"). ${ }^{(20)}$ It can be observed in Table (4) that periodontal disease was prevalent in $97.5 \%$ of the sample with only $2.5 \%$ of the students having healthy gingiva. This figure is comparable to that in Mosul in the previous study ${ }^{(16)}$ as the disease was $98.58 \%$ prevalent, also $65.9 \%$ of the sample 
showed calculus as a highest score in the total sample, this figure is slightly lower then that reported by Al-Naimi ${ }^{(16)}$ that reported that three quarters of the sample had calculus as the highest score. In this study, no significant age difference was observed in dental health of the sample with in the 3 age groups, this is in agreement with the previous study. ${ }^{(16)}$

Females tended to have a healthier gingiva $3.6 \%$ compared to $1.2 \%$ in males with significant gender difference; also the mean number of healthy sextants was greater in females 2.04 compared to males 1.23. Many studies have consistently shown that periodontal diseases are more prevalent in boys than in girls, ${ }^{(27,28)}$ which might be attributed to poorer oral hygiene level and hormonal and other physiological and behavioural differences in boys which may also contribute to this higher risk for periodontal diseases.

The periodontal treatment needs of the students is seen in Table (5), only $2.5 \%$ of the total sample needed no treatment, while $97.5 \%$ of the total sample needed oral hygiene education and instructions, which is an important part of oral health promotion and has been considered an essential and basic part of dental health services. Oral health education aims to promote oral health through educational means, principally the provision of information to improve oral health knowledge and awareness for adoption of a healthier lifestyle, changed attitudes, and desirable behaviours. ${ }^{(29)}$

In Iraq, promotion of oral health should be performed in schools, aiming at developing healthy lifestyles and self-care practices in children and young people, this is considered one of the most recent policies and strategies recommended. An integrated approach that combines school health policy, skill-based health education, a health-supportive school environment, and school health services can tackle major common risk factors and contribute to effective control of oral disease. ${ }^{(14)}$

Our results also showed that $65.9 \%$ of the total sample needed professional scaling and polishing. The present findings of the poor level of oral hygiene and high proportion of 15 -year-olds with gingival bleeding and calculus are in line with pre- vious findings from many developing countries. $^{(30)}$

In a population with low levels of oral hygiene and limited resources for oral health care, such as Iraq, it is reasonable to empower the children to promote their dental health and to prevent oral diseases through dental health education. Oral health promotion programmes in schools should be set as a high priority goal for health policy in Iraq. This means that educational activities also need to be targeted at decision-makers for building a supportive environment in Iraq to minimize or eliminate risky behaviours. Also, regular dental screening programs with dental professionals within schools could be beneficial.

Sugars are undoubtedly the most important dietary factor in the aetiology of dental caries. ${ }^{(6)}$ Sugar availability was low in Iraq during the 13 years of sanctions and therefore consumption was restricted to rich families who could afford expensive sugar products. This study was carried out after a reasonable period of the end of the sanctions when sugar products had become commonly available to the whole population causing a sudden elevation in sweet consumption among the population and this was evident in the marked rise in DMFT values. So dental health education stressing on sugar restriction is critical .Also exposure to fluoride been shown to have an additive effect on caries reduction, in our country many options are present that were not available previously, which include fluoride tablets, mouth rinses and varnishes that have proved to be very effective in caries reduction, ${ }^{(25)}$ also fissure sealants can be used to effectively seal susceptible teeth or teeth with initial enamel caries to halt and prevent dental caries. ${ }^{(31)}$

\section{CONCLUSIONS}

The trends of dental caries has increased since the previous survey and requires many types of dental treatment needs especially one surface fillings, while gingival health showed the same worse picture, with majority of the sample requiring oral hygiene instructions, also a large proportion required professional scaling and pol- 
ishing. To improve children's oral health, school-based oral health educational programs should be established starting from primary and extending to intermediate schools, stressing on sugar restriction and oral hygiene measures, fluorides and fissure sealants can be used.

\section{REFERENCES}

1. Greenspan D. Oral health is global health. J Dent Res. 2007; 86: 485

2. Petersen PE. The World Oral Health Report: Continuous improvement of oral health in the $21^{\text {st }}$ century - The approach of the WHO Global Oral Health Program. Community Dent Oral Epidemiol. 2003; 31(1): 3-24.

3. Sheiham A, Watt R. Oral health promotion and policy. In: Murray JJ, Nunn JH, Steele JG.n Prevention of oral disease. 4th ed. Oxford, Oxford University Press, 2003. Pp: 241-258.

4. Petersen PE, Bourgeois D, Ogawa H, Estupinan-Day S, Ndiaye C. The global burden of oral diseases and risks to oral health. Bull World Health Organ. 2005; 83: 661-669.

5. Fejerskov O, Kidd EAM (eds). Dental caries: The Disease and its Clinical Management. $2^{\text {nd }}$ edn. Copenhagen, Denmark. Blackwell Monksgaard. 2008; p: 123.

6. Moynihan P, Petersen PE. Diet, nutrition and the prevention of dental diseases. Public Health Nutr. 2004; 7: 201-226.

7. Pihlstrom BL, Michalowicz BS, Johnson NW. Periodontal diseases. Lancet. 2005; 366: 1809- 1820.

8. Mariotti A. Dental Plaque-Induced Gingival Diseases. J Period Online. 1999; 4(1): 7-17.

9. Petersen PE, Ogawa H. Strengthening the prevention of periodontal disease: The WHO approach. J Periodontol. 2005; 76: 2187-2193.

10.Löe $\mathrm{H}$. Oral hygiene in the prevention of caries and periodontal disease. Int Dent J. 2000; 50: 129- 139.

11.World Health Organization. Oral Health Surveys-Basic Methods. $4^{\text {th }}$ ed. Geneva: World Health Organization. 1997.

12.Klein H, Palmer CE, Knutson JW. Studies on dental caries. I. Dental status and dental needs of elementary school children. Public Health Rep. 1938; 53(19): 751-
765.

13.World Health Organization. Oral Health Surveys-Basic Methods. $3^{\text {rd }}$ ed. Geneva: World Health Organization. 1987.

14.Petersen PE. Oral Health. In: Kris Heggenhougen and Stella Quah (eds). International Encyclopedia of Public Health, Vol 4. San Diego: Academic Press. 2008; Pp: 677-685.

15. Saied-Moallemi Z, Virtanen JI, Vehkalahti MM, Tehranchi A, Murtomaa H. School based intervention to promote preadolescents' gingival health: A community trial. Community Dent Oral Epidemiol. 2009; 37: 518-526.

16.Al-Naimi RJ. Oral health status and treatment needs in 13-15 year old students in Mosul City, Iraq. MSc thesis. University of Mosul. College of Dentistry. 1998

17.Jamel H, Plasschaert A and Shieham A. Dental caries experience and availability of sugars in Iraqi children before and after the United Nations sanctions. Int Dent J. 2004; 54(1): 21-25.

18.Jamel HA, Sheiham A, Watt RG et al. Sweet preference, consumption of sweet tea and dental caries; studies in urban and rural Iraqi populations. Int Dent $J$. 1997; 47: 213-217

19.Ahmed NAM, Åstrøm AN, Skaug N and Petersen PE. Dental caries prevalence and risk factors among 12-year old schoolchildren from Baghdad, Iraq: A post-war survey. Int Dent J. 2007; 57: 36-44.

20.World Health Organization (WHO) regions, 1995-2005 available at (http://www.whocollab.od.mah.se/index. html) .Accessed January 2011.

21.WHO (World Health Organization, 2003). WHO information series on school health, Doc11; Oral health promotion through schools, Geneva, WHO 2003.

22.Watt RG. Strategies and approaches in oral disease prevention and health promotion. Bull World Health Organ. 2005; 83: 711-718.

23. Anusavice KJ. Present and future approaches for the control of caries. J Dent Educ. 2005; 69: 538-554.

24.Vanobbergen J, Declerck D, Mwalili S, Martens L. The effectiveness of a 6-year oral health education program for primary schoolchildren. Community Dent Oral 
Epidemiol. 2004; 32: 173-182.

25. Marinho VC. Cochrane reviews of randomized trials of fluoride therapies for preventing dental caries. Eur Arch Paediatr Dent. 2009; 10: 183-191.

26.Kallestål C. The effect of five years' implementation of caries preventive methods in Swedish high-risk adolescents. Caries Res. 2005; 20-26.

27.Jenkins WMM, Papapanou PN. Epidemiology of periodontal disease in children and adolescents. Periodontol 2000. 2001; 26: 16-32.

28.Timmerman MF, van der Weijden GA. Risk factors for periodontitis. Int $J$ Dent
Hyg. 2006; 4: 2-7.

29. Murray JJ, Nunn JH, Steele JG. Prevention of Oral Disease. $4^{\text {th }}$ ed. Oxford: Oxford University Press. 2003; Pp: 7-34, 77-95, 123-144, 241-258.

30.Albandar JM, Tinoco EMB. Global epidemiology of periodontal diseases in children and young persons. Periodontol 2000. 2002; 29: 153-176.

31.Leskinen K, Salo S, Suni J, Larmas M. Comparison of dental health in sealed and non-sealed first permanent molars: 7 years follow-up in practice based dentistry. J Dent. 2008; 36: 27-32. 